\title{
Fakta El Gibor Dalam Kisah Gideon dan Pergumulan Kaum Miskin Asia : Suatu Konstruksi Teologi Kontekstual Asia
}

\begin{abstract}
Deky Nofa Aliyanto
Sekolah Tinggi Teologi Berea, Salatiga dekytheo@gmail.com

Diterima : 6 Nov. 2019

Direvisi : 22 Nov. 2019

Disetujui : 25 Nov. 2019

\section{Abstrak}

Masalah kemiskinan menjadi pergumulan sebagian besar masyarakat Asia sampai hari ini sehingga usaha berteologi harus menyentuh realitas itu. Usaha tersebut mungkin dikerjakan karena fakta El Gibore dalam kisah Gideon berkaitan dengan masalah kemiskinan. Tujuan penelitian ini adalah membangun kontruksi teologi kontekstual Asia berdasarkan fakta El Gibor dalam kisah Gideon dan pergumulan kaum miskin Asia. Penelitian ini menggunakan pendekatan kualitatif dengan menggunakan kajian Teologi Biblika dan Teologi Kontekstual dengan prosedur mencakup: Pertama, mendeskripsikan pergumulan kaum miskin Asia, Kedua, mengeksegesis fakta El Gibor dalam kisah Gideon dalam kaitannya dengan pergumulan kemiskinan, ketiga, mereduksi kedua data tersebut sehingga dapat membangun konstruksi teologi kontekstual Asia dan Keempat, menarik kesimpulan. Hasil penelitian mencakup: Adanya perjumpaan kemiskinan Asia dan Israel zaman Gideon dalam dimensi ekonomis, sosiologis, psikologis dan mesinanis. Teisme bagi kaum miskin Asia adalah Allah yang memperjuangkan nasib kaum miskin yang hadir dalam penderitaan. Manusia dari realitas kemiskinan Asia terdiri dari kaum penindas dan tertindas yang keduanya memerlukan kasih Allah.
\end{abstract}

Kata kunci: Kaum miskin Asia, El Gibor, kisah Gideon, Konstruksi.

\begin{abstract}
The problem of poverty has been a struggle for most Asian societies to this day, so theological effort must touch that reality. The effort may be done because of the fact El Gibore in the story of Gideon is related to poverty. The purpose of this study is to construct the construction of Asian contextual theology based on the facts of El Gibor in the story of Gideon and the struggle of the Asian poor. This study uses a qualitative approach using the study of Biblical Theology and Contextual Theology with procedures including: First, describing the struggles of the poor in Asia, Second, exhorting the facts of El Gibor in the Gideon story in relation to poverty struggles, third, reducing the two data so as to build construction Asian and Fourth contextual theology, drawing conclusions. The results of the study include: The existence of the Gideon-era Asian and Israeli poverty encounters in economic, sociological, psychological and mechanical dimensions. Humans from the reality of Asian poverty are made up of oppressors and oppressed who both need God's love.
\end{abstract}

Keywords: Asian poor, El Gibor, Gideon's story, Construction. 


\section{PENDAHULUAN}

Beriman bukanlah suatu fakta tanpa juntrungan, antara langit dan bumi. Beriman baru bermakna apabila itu terjadi di dalam persentuhan yang sangat kongkret dengan dunia nyata. ${ }^{1}$ Disinilah tugas teologi kontekstual menjadi sangat penting karena mampu menyentuhkan sekaligus mendialogkan konteks masa lampau yang terekam dalam kitab suci dan konteks aktual masa kini. Keadaan Indonesia adalah suatu kenyataan masa kini yang menjadi bagian integral bagi masyarakat Asia termasuk orang-orang Kristen yang tinggal didalamnya. Misalnya dalam konteks Indonesia sampai hari ini, masalah kemiskinan merupakan sebagian besar realitas yang perlu mendapatkan banyak perhatian. Oleh sebab itu tugas teologi kontekstual menjadi penting karena mampu menyentuhkan dan mendialogkan Asia dalam konteks kemiskinan dengan konteks Alkitab atau sebaliknya konteks Alkitab dengan konteks Asia secara kongkret. Tugas demikian menurut Bevans tidak mungkin ditolak karena merupakan sebuah imperatif teologis. Sebagaimana yang dipahami tentang teologi dewasa ini maka kontekstualisasi merupakan bagian dari hakikat terdalam teologi itu sendiri. ${ }^{2}$

Usaha untuk mendialogkan Asia dalam konteks kemiskinan dengan konteks Alkitab atau sebaliknya, mungkin dikerjakan mengingat adanya teks-teks Alkitab yang di dalamnya bertautan dengan fakta tentang kemiskinan. Salah satu teks itu terdapat dalam kisah Gideon yang secara pasti juga sedang mempergumulkan masalah kemiskinan bagi dirinya dan bangsa Israel. Fakta demikian secara tegas tercatat dalam Hakim-Hakim 6: 6 bahwa Israel menjadi sangat melarat oleh karena penindasan dari orang-orang Midian. Menjadi menarik karena pembebasan Israel dari kemiskinan dalam kisah Gideon bertalian dengan perbuatan-perbuatan Allah. Berdasarkan realitas inilah maka penelitian ini mengambil tema: Fakta El Gibor Dalam Kisah Gideon dan Pergumulan Kaum Miskin Asia: Suatu Konstruksi Teologi Kontekstual Asia. Adapun isi dari penelitian ini mencakup pertama: Pergumulan Kaum Miskin Asia. Kedua: El gibbowr dan pergumulan kemelaratan dalam kisah Gideon. Ketiga: Konstruksi teologi kontekstual Asia berdasarkan fakta El Gibor dalam kisah Gideon dan pergumulan kaum miskin Asia. Keempat: Kesimpulan. Dari pendahuluan diatas dapat diambil sebuah rumusan masalah, yaitu bagaimana

\footnotetext{
${ }^{1}$ Weinata Sairin, Iman Kristen Dan Pergumulan Kekinian (Bandung: Bina Media Informasi, 2012).7.

${ }^{2}$ Stephen Bennet Bevans, Model-Model Teologi Kontekstual (Flores: Penerbit Ledalero, 2002).1.
} 

kaitanya dengan pergumulan Kaum Miskin Asia?

Penelitian ini bertujuan untuk membangun konstruksi Teologi Kontekstual Asia berdasarkan fakta El Gibor dalam Kisah Gideon dan Pergumulan Kaum Miskin Asia. Secara teoritis penelitian ini diharapkan memberikan kontribusi ilmiah dalam kajian teologi Biblika dan kontekstual dalam arti menghubungkan dan mendialogkan hasil kajian Biblika secara Kontekstual terutama dalam isu kemiskinan. Secara praktis menggugah dan mendorong keterlibatan pembaca Kristen untuk menggumuli persoalan kemiskinan yang ada disekitarnya.

\section{METODE PENELITIAN}

Penelitian ini menggunakan metodologi kuwalitatif dengan pendekatan Teologi Biblika dan Teologi Kontekstual. Teologi Biblika mencakup pendekatan hermeneutik untuk pengkajian Alkitab dengan tujuan memahami makna teks dalam konteks penulis mula-mula. ${ }^{3}$ Teologi kontekstual dengan model Sintesis yang memberikan penekanan pada pengalaman masa kini (yakni konteks: pengalaman, kebudayaan, lokasi sosial, perubahan sosial) dan pengalaman masa lampau (Kitab Suci dan tradisi).. Analisis yang digunakan dalam penelitian ini adalah dengan menggunakan metode interaktif yaitu pengumpulan data, penyajian data, reduksi data dan penarikan kesimpulan. ${ }^{5}$

\section{HASIL DAN PEMBAHASAN}

\section{Pergumulan Kaum Miskin Asia}

\section{Realitas Asia - Indonesia}

Kemiskinan merupakan pergumulan sebagian besar rakyat Asia sampai hari Ini. Menurut Drewes dan Mojau dalam teologi dunia ketiga yaitu periode tahun 1960 sampai sekarang, kekristenan dalam konteks Asia diperhadapkan dengan masalah pergumulan orang miskin. ${ }^{6}$

\footnotetext{
${ }^{3}$ Andreas B. Subagyo, Pengantar Riset Kuantitatif Dan Kualitatif (Bandung: Kalam Hidup, 2004). 118

${ }^{4}$ Bevans, Model-Model Teologi Kontekstual. 162.

${ }^{5}$ M. B. Miles and A. M. Huberman, Qualitative Data Analysis: A Sourcebook of New Methods; Qualitative Data Analysis: A Sourcebook of New Methods (California: Sage Publication Inc, 1994).23.

${ }^{6}$ B.F. Drewes and Julianus Mojau, Apa Itu Teologi? Pengatar Ke Dalam Ilmu Teologi (Jakarta: BPK Gunung Mulia, 2003).67.
} 
Sudut pandang dari Drewes dan Mojou harus diakui sangat relevan kerena memang demikianlah realitas dari konteks Asia. Pieris pun sebagaimana dikutip oleh Listiabudi menjelaskan bahwa “konteks Asia memperhadapkan Kekristenan dengan dua karakteristik, yaitu kemiskinan yang merajalela dan keberagaman yang multirupa atau plural." ${ }^{7}$ Asia dengan 85 sampai $90 \%$ penduduk dunia yang miskin, adalah suatu benua dengan jumlah penduduk yang besar dan senantiasa terus bertambah. Lebih dari 40\% penduduk Asia berusia di bawah 14 tahun dan hanya 5\% yang diatas 60 tahun. Angka pertumbuhan penduduk rata-rata adalah 2,1\% per tahun di seluruh Asia. ${ }^{8}$ Itulah sebabnya Yewangoe mengatakan "memang benar, secara sosial-ekonomi, mayoritas bangsabangsa di Asia miskin. Kebanyakan negara Asia dianggap tergolong apa yang disebut negaranegara berkembang." ${ }^{\prime 9}$ Dewan-dewan Gereja Asia di Kandy menyatakan "Asia secara khusus dipengaruhi oleh masalah kemiskinan yang amat dasyat, masalah yang benar-benar menimpa sebagian besar umat manusia di seluruh dunia."10 Realitas demikian seharusnya menjadi undangan bagi cendikiawan Kristen untuk membangun teologi yang kontekstual, ${ }^{11}$ Sebagaimana dikemukakan oleh Stevanus bahwa memang teologi itu seharusnya kontekstual. Teologi kontekstual semestinya dipandang sebagai kebutuhan gereja. Sebab itu, gereja tidak boleh melalaikan peran aktifnya di bidang sosial sehingga memberikan pengaruhnya yang positif (terang dan garam) dalam kehidupan sosial di masyarakat, hal ini khususnya dalam pergumulan kaum miskin Asia.

Problema kemiskinan terus menjadi masalah besar sepanjang sejarah Indonesia sebagai sebuah negara. Dalam negara yang salah urus, tidak ada persoalan yang lebih besar, selain persoalan kemiskinan. Kemiskinan telah membuat jutaan anak-anak tidak bisa mengenyam pendidikan yang berkualitas, kesulitan membiayai kesehatan, kurangnya tabungan dan tidak adanya investasi, kurangnya akses ke pelayanan publik, kurangnya lapangan pekerjaan,

\footnotetext{
${ }^{7}$ Daniel K. Listijabudi, Bergulat Di Tepian: Pembacaan Lintas Tekstual Dua Kisah Mistik (Dewa Ruci Dan Yakub Di Yabok Untuk Membangun Perdamaian (Jakarta: BPK Gunung Mulia, 2019).48.

${ }^{8}$ Tissa Balasuriya, Teologi Siarah (Jakarta: BPK Gunung Mulia, 2004).3.

${ }^{9}$ A.A Yewangoe, Theologia Crucis Di Asia: Pandangan-Pandangan Orang Kristen Asia Mengenai Penderitaan Dalam Kemiskinan Dan Keberagaman Di Asia (Jakarta: BPK Gunung Mulia, 2004).9.

${ }^{10}$ Message To The Asian Communities: Final Statement of The Kandy Confrence, Dialogue (seri baru), VII (Sept. - Des 1980), 119.

${ }^{11}$ Kalis Stevanus, “Mengimplementasikan Pelayanan Yesus Dalam Konteks Misi Masa Kini Menurut Injil Sinoptik," Jurnal Fidei 1, no. 2 (2018): 287.
} 
kurangnya jaminan sosial dan perlindungan terhadap keluarga, menguatnya arus urbanisasi ke kota, dan yang lebih parah, kemiskinan menyebabkan jutaan rakyat memenuhi kebutuhan pangan, sandang dan papan secara terbatas. ${ }^{12}$ Pada masa orde baru pernah ada ketentuan tidak tertulis yang melarang wacana mengenai kemiskinan dan penderitaan rakyat, karena dianggap meremehkan hasil-hasil pembangunan yang telah dicapai. Padahal, sukses pembangunan tercapai karena orang miskin dikorbankan. Contoh yang paling jelas terlihat adalah pembuatan waduk Kedungombo yang menghebohkan di sekitar tahun $80-a n .{ }^{13}$ Sekarang ini, berdasarkan data Badan Pusat Statistik (BPS) jumlah penduduk miskin di Indonesia pada Maret 2019 mencapai 25,14 juta jiwa atau sekitar 9,82\% dari total penduduk. Pulau Jawa mendominasi dengan sebaran: Jawa Timur dengan jumlah penduduk miskin 4,11 juta jiwa, Jawa Tengah 3,74 juta jiwa, dan Jawa Barat 3,4 juta jiwa. Secara regional, penduduk miskin di Pulau Jawa mencapai 12,74 juta jiwa atau separuh total penduduk miskin di tanah air. ${ }^{14}$

\section{Dimensi Kemiskinan Asia}

Menurut pandangan Friedman seperti dikutip oleh Purwanto, kemiskinan juga berarti ketidaksamaan kesempatan untuk mengakumulasikan basis kekuasaan sosial. Basis kekuasaan sosial ini meliputi: (1) Modal produktif seperti tanah, alat produksi, perumahan, kesehatan. (2) Sumber keuangan. (3) Organisasi sosial dan politik yang dapat digunakan untuk kepentingan bersama seperti koperasi, partai potitik, organisasi sosial,(4) Jaringan sosial, (5) Pengetahuan dan ketrampilan. (6) Informasi yang berguna untuk kemajuan h.dup. ${ }^{15}$ Senada dengan hal itu Todaro dan Smith menyatakan bahwa kemiskinan merupakan masalah global yang dihadapi dan menjadi perhatian orang di dunia. Negara miskin masih dihadapkan antara masalah pertumbuhan dan distribusi pendapatan yang tidak merata sementara itu, banyak negara berkembang yang mengalami pertumbuhan ekonomi yang tinggi namun, kurang memberikan manfaat bagi

12 Nano Prawoto, “Memahami Kemiskinan Dan Strategi Penanggulangannya," Jurnal Ekonomi dan Studi Pembangunan 9, no. 1 (2009): 56-68.

${ }^{13}$ Emanuel Gerrit Singgih, Iman Dan Politik Dalam Era Reformasi Di Indonesia (Jakarta: BPK Gunung Mulia, 2002).49.

${ }^{14}$ https://www.bps.go.id/pressrelease/2019/07/15/1629/persentase-penduduk-miskin-maret-2019sebesar-9-41-persen.html. Diakses tanggal 15 November 2019 jam 11:32Wib.

${ }^{15}$ Erwan Agus Purwanto, “Mengkaji Potensi Usaha Kecil Dan Menengah (UKM) Untuk Pembuatan Kebiiakan Anti Kemiskinan Di Indonesia," Jurnal IImu Sosial dan IImu Politik 10, no. 3 (2019): 295-296. 
LOGIA : Jurnal Teologi Pentakosta

Vol. 1, No. 1 (Desember 2019)

ISSN : 2716-4322 (Cetak) 2716-2834 (Online)
Available Online at

http://sttberea.ac.id/e-journal/index.php/logia

DOI : $10.37731 / \log . v 1 i 1.23$

penduduk miskinnya. ${ }^{16}$ Dengan kata lain, kemiskinan adalah situasi yang serba terbatas yang terjadi bukan atas kehendak orang yang bersangkutan. Suatu penduduk dikatakan miskin bila ditandai oleh rendahnya tingkat pendidikan, produktivitas kerja, pendapatan, kesehatan dan gizi serta kesejahteraan hidupnya, yang menunjukkan lingkaran ketidakberdayaan. Kemiskinan bisa disebabkan oleh terbatasnya sumber daya manusia yang ada, baik lewat jalur pendidikan formal maupun nonformal yang pada akhirnya menimbulkan konsekuensi terhadap rendahnya pendidikan informal.

Menurut Laksmi, kemiskinan dikaitkan dengan keadaan seseorang yang tidak sejahtera atau serba kekurangan dalam kehidupan sosial ekonomi. Kaum miskin juga tergolong sebagai masyarakat marjinal yaitu buruh, petani miskin, nelayan, pedagang kecil, perempuan, anak-anak, masyarakat difable dan kaum miskin perkotaan. ${ }^{17}$ Oleh sebab itu kriteria miskin menurut Mulyono terbagi menjadi dua yaitu secara fisik dan non fisik, secara fisik terdiri dari status kepemilikan tanah, status sosial, status kepemilikan rumah, aset yang dimiliki, sedang non fisik terdiri dari pekerjaan, pendapatan, pengeluaran, potensi dan pengangguran. ${ }^{18}$ Menariknya, dalam kaitan antara kaum miskin sebagai masyarakat marginal, Alanudin menemukan bahwa kemiskinan masyarakat marginal memiliki pengaruh terhadap solidaritas sosial: (1) Latar belakang yang sama menyebabkan gaya hidup gotong royong. (2) Solidaritas ini membuat masyarakat tetap dapat memenuhi kebutuhan hidupnya. (3) Solidaritas diantara mereka membuat mereka bisa bertahan hidup ditengah kemiskinan. Solidaritas sosial menjadi faktor keberlangsungan hidup mereka. ${ }^{19}$

Bagi Pieris kemiskinan sesungguhnya berdimensi ganda yaitu psikologis-sosiologis. Wajah kemiskinan yang secara psikologis memperbudak menampakan dirinya dalam kemiskinan yang dipaksakan, yang melanggar harkat manusia (keterasingan). Sementara secara sosiologis,

\footnotetext{
${ }^{16}$ Ayu Setyo Rini and Lilik Sugiharti, "Faktor-Faktor Penentu Kemiskinan Di Indonesia: Analisis Rumah Tangga," Jurnal Ilmu Ekonomi Terapan 1, no. 2 (2016).

17 Laksmi, "Kemiskinan Informasi Pada Masyarakat Marjinan Di Indonesia," Jurnal Al-Maktabah 4, no. 2 (2004): 93-94.

${ }^{18}$ Sungkowo Edy Mulyono, “Model Pemberdayaan Masyarakat Miskin Melalui Jalur Pendisikan Formal Di Kecamatan Gajah Mungkur Kota Semarang," Jurnal Edukasi 2, no. 1 (2017): 1.

${ }^{19}$ Muhamad Alif Alaudin, Kemiskinan Masyarakat Marginal dan Pengaruhnya Terhadap Solidaritas Sosial Https://Www.Academia.Edu/37891276/Kemiskinan_Masyarakat_Marginal_Dan_Pengaruhnya_Terhadap_Solidarit as_Sosial. Diakses Tanggal 19 November 2019.
} 
LOGIA : Jurnal Teologi Pentakosta

Vol. 1, No. 1 (Desember 2019)

ISSN : 2716-4322 (Cetak) 2716-2834 (Online)

kemiskinan dipandang sebagai (perbu

perbudakan orang banyak oleh hamba-hamba Mamon (perekrutan hak, perekrutan harta milik, dll). Pada pihak lain, wajah kemiskinan yang secara psikologis membebaskan tampak dalam pembebasan batin seseorang dari Mamon, sementara wajahnya yang secara sosiologis membebaskan, kata Pieris, dapat dilihat dalam caranya menciptakan solidaritas dalam dasar bersama pembebasan masyarakat manusia. ${ }^{20}$ Dalam dimensi sosiologis kemiskinan inilah maka Kagawa seperti dikutip Kwang mencoba untuk mengkristenkan dan memanusiakan tatanan sosial. Sebagai sosialis Kristen, ia memedulikan mereka yang sakit dan terlantar, mencoba menyerikatkan baik kaum pekerja industri maupun masyarakat desa ketika hal tersebut masih illegal. Kebanyakan kondisi menyedihkan dan kemiskinan daerah kumuh disebabkan oleh pengaruh industrialisasi suatu bangsa. ${ }^{21}$

Berbicara mengenai kemiskinan dalam buku "Theologia Crucis di Asia," Yewangoe menyatakan bahwa pada kenyataanya kemiskinan sering hadir dalam penderitaan. ${ }^{22}$ Dalam kasus ini, kemiskinan dialami sebagai penderitaan yang sebenarnya. Orang-orang yang hidup dalam situasi miskin benar-benar memandangnya sebagai sesuatu yang buruk, yang karenanya perlu diubah. Mereka bereaksi terhadap situasi buruk ini dengan mencoba menemukan alternatif-alternatif. Terkadang alternatif-alternatif itu dicari dalam protes-protes terhadap “kelas yang berkuasa" yang dianggap sebagai penyebab penderitaan mereka. Terkadang alternatifnya itu dicari dalam rencana-rencana pembangunan, atau melalui partisipasi dalam rencana-rencana yang sudah ada. Orang juga mencari alternatif dalam pengharapan mesianis, suatu keyakinan dan kerinduan akan datangnya juruselamat yang akan mengantarkan masa depan yang lebih baik.

Jika Yewangoe memahami kemiskinan sebagai penderitaan maka Koyama sebagaimana dikutip oleh Sugirtharajah memahami kemiskinan sebagai "rakyat yang dimeranakan." Bagi Koyama kelimpahruahan dan suatu tingkat kemiskinan yang tidak manusiawi kini ada bersamasama di dalam dunia ini. Kenyataan yang paling menonjol dari penderitaan Asia adalah bahwa

${ }^{20}$ Pieris, "The Dinamic of the Act, a Reply to the Editor of Satyodaya," Bulletin Of Satyodaya Centre for Social Research and Encounter 7, no. 3 (1979): 23-28.

${ }^{21}$ Hwa Yung, "Mangga Atau Pisang? Sebuah Upaya Pencarian Teologi Kristen Asia Yang Autentik," Literatur Perkantas (2017): 199.

${ }^{22}$ A.A Yewangoe, Theologia Crucis Di Asia: Pandangan-Pandangan Orang Kristen Asia Mengenai Penderitaan Dalam Kemiskinan Dan Keberagaman Di Asia. 16 
rakyat dimeranakan. Dimeranakan oleh kelaparan, siksaan, perampasan hak-hak; dimeranakan oleh penghisapan ekonomi, diskriminasi ras dan etnis, penindasan seksual; dimeranakan oleh kesepian, keterasingan dan perpecahan. Menurutnya ada perbedaan antara seekor anjing yang lapar dan seorang manusia yang lapar. Manusia yang lapar merasa martabatnya sebagai manusia di serang; anjing yang lapar tidak. Bagi diri manusia, penghinaan jasmaniah berarti penghinaan rohaniah. Perut yang lapar berarti penghinaan pada gambar Allah. ${ }^{23}$

Selain itu, dalam Konteks Asia, kemiskinan harus pula diakui berkaitan erat dengan masalah lingkungan hidup. Misalnya almarhum Indira Gandhi, bekas perdana Menteri India berkata pada tahun 1972: "Kemiskinan adalah penyebab polusi yang tertinggi. Jika Anda ingin kami tidak membuat polusi, bantulah kami untuk menghapuskan kemiskinan." 24 Pernyataan almarhum Indira Gandhi sebenarnya mengandung pesan bahwa masalah kemiskinan berkaitan erat dengan masalah rusaknya lingkungan hidup.

Berbagai konfrensi internasional (termasuk KTT Bumi di Rio de Janeiro-Brasil, BaliIndonesia, dan terakhir konfrensi perubahan iklim di Copenhagen-Denmark, 2009), negara Selatan selalu menuntut keterikatan antara lingkungan hidup dan pengurangan kemiskinan. Mengalirnya kekayaan dan sumber daya alam dari negara Selatan ke Utara adalah sumber kerusakan hutan dan lingkungan hidup. Penggundulan hutan dan eksploitasi sumber alam yang merusak lingkungan hidup sering disebabkan oleh keserakahan dan kemiskinan manusia. ${ }^{25}$

Hal ini berarti, bangsa-bangsa dunia Ketiga semakin merasakan beban yang harus dipikulnya karena terpaksa menanggung bahan-bahan mentah yang murah dan tenaga kerja yang murah dan menyediakan pasar bagi negara-negara 'maju', negara-negara yang lebih berkembang'. Mereka telah menjadi ancaman bagi seluruh sistem itu, cara-cara berpikirnya, nilainilainya, dan struktur-strukturnya. Dalam keseluruhan tantangan dari dunia ketiga tersebut, Asia menyodorkan pelbagai masalah yang secara mendasar mempertanyakan kelangsungan tatanan dunia itu. ${ }^{26}$

${ }^{23}$ R.S. Sugirtharajah, Wajah Yesus Di Asia (Jakarta: BPK Gunung Mulia, 1996).

${ }^{24}$ Josef P. Widyamadja, Yesus Dan Wong Cilik: Praksis Diakonia Transformatif Dan Teologi Rakyat Di Indonesia (Jakarta: BPK Gunung Mulia, 2017).

$25 \mathrm{lbid}$.

${ }^{26}$ Tissa Balasuriya, Teologi Siarah. 
Berdasarkan beberapa pandangan itu maka kemiskinan Asia sebenarnya mencakup dimensi ekonomis, sosiologis, psikologis dan mesianis. Dalam dimensi ekonomis terlihat bahwa masalah kemiskinan Asia menyebabkan mereka hidup dalam lingkaran ketidakberdayaan sehingga mengalami rendahnya tingkat pendidikan, produktivitas kerja, kesehatan dan gizi. Dalam dimensi sosiologis terlihat bahwa masalah kemiskinan Asia menyebabkan terjadinya kelas sosial dimana kaum kaya memperbudak kaum miskin demi semakin bertambah kaya. Bahkan sejatinya kebijakan-kebijakan atas nama pembangunan justru semakin memiskinkan kaum miskin itu sendiri. Namun disisi lain, kemiskinan melahirkan solidaritas yang menjadikan mereka sanggup bertahan hidup. Dalam dimensi psikologis terlihat bahwa masalah kemiskinan Asia menyebabkan kaum miskin merasa terasing, menderita dan merana bahkan merasa tidak memiliki martabat. Keinginan untuk lepas dari situasi demikianlah yang kemudian menyebabkan kaum miskin Asia hidup dalam harapan mesianis sebagai salah satu alternatif pembebasan mereka dari kemiskinan.

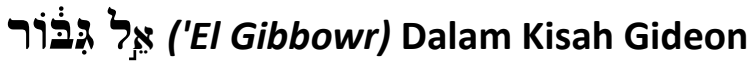

\section{Pengertian}

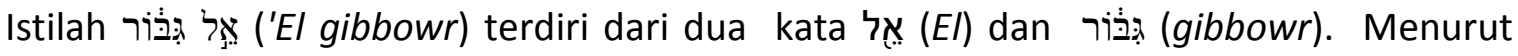
Berkhof nama yang paling sederhana yang denganya Allah disebut dalam Perjanjian Lama adalah nama " $E l$ ", yang sangat mungkin berasal dari kata ul, yang berarti menjadi yang pertama, menjadi tuan, dan juga berarti kuat dan berkuasa. ${ }^{27}$ Dyrness mengatakan "El" adalah penyebutan tertua untuk Allah bagi bangsa Semit. Arti dasarnya ialah seorang pemimpin besar atau seorang gubenur yang menekankan jarak antara Allah dan manusia, seperti juga kuasa-Nya atas alam karena Bangsa Israel termasuk dalam rumpun bangsa Semit. "El" biasanya dihubungkan dengan pemimpin-pemimpin tertentu. ${ }^{28}$ Memang "El" semula dikenal sebagai Allah di atas allah (The Supreme God) atau Allah Maha Tinggi (The Most High God) dan dalam Alkitab Ibrani digunakan untuk menyebut Allah Israel. ${ }^{29}$ Menjadi lebih menarik karena "El" dalam tradisi Alkitab sering digunakan sebagai

\footnotetext{
${ }^{27}$ Louis Berkhof, Teologi Sistematika: Doktrin Allah (Lembaga Reformed Injili Indonesia, 1997).70.

${ }^{28}$ William Dyrness, Tema-Tema Dalam Teologi Perjanjian Lama (Malang: Gandum Mas, 2004).30.

29 "El" sebagai nama diri disejajarkan dengan nama Yahweh (Kej. 28:16-19), dan dalam sajak Bileam disebut bahwa "El" tidak lain adalah Yahweh yang membawa umat Israel keluar dari Mesir (Bil. 23: 8, 19, 22-23; 24:4, 8, 16, 23) dan di tempat lain nama "El" disebut lagi sebagai sejajar dengan Yahweh (Mzm. 85: 8-9; Yes. 42:5). Herlianto, Siapakah Yang Bernama Allah Itu? (Jakarta: BPK Gunung Mulia, n.d.).15.
} 
pengganti nama Yahweh. Distribusi penggunaan " $E l$ " sebagai nama diri sama dengan Yahweh memang sangat tidak teratur tetapi penting dan sering digunakan dalam kesusastraan Israel yang awal. $^{30}$

"El" sering dirangkaikan dengan istilah-istilah El Shaddai, El Alion, El Olam ${ }^{31}$ dan lain-lain, namun fokus dalam tulisan ini adalah istilah El yang dirangkaikan dengan istilah Gibbowr sehingga membentuk penyebutan Allah sebagai אִּ (El Gibbowr). Holladay mengartikannya sebagai kekuatan, keperkasaan dan digambarkan sebagai pahlawan perang atau sang pemenang." 32 “Sedangkan Kohler dan Baumgartner lebih menekankan Gibborw dalam istilah 'kemiliteran' yang berarti pengawal yang perkasa, pasuken elit, prajurit perang yang menang dalam peperangan dan pahlawan yang menyelamatkan." ${ }^{33}$ Senada dengan pengertian tersebut Rabbi Kirt Schneider menyatakan bahwa בָּ ('El Gibbowr) is the description of God as a Mighty Warrior and Champion. He always prevails, has great strength, and authority over all. It is He who spoke all of creation into existence. It is His mighty hand that brought the ten plagues against Egypt and

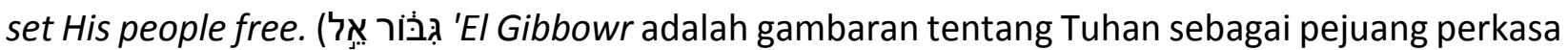
dan Sang Juara. Dia selalu menang, memiliki kekuatan besar, dan otoritas atas semuanya. Dialah yang mengatakan semua ciptaan menjadi ada. Itu adalah tangan-Nya yang besar yang membawa

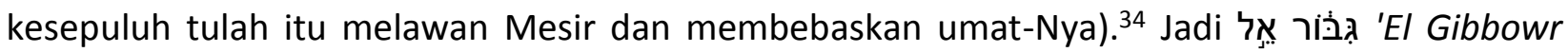
dalam tulisan ini dipahami sebagai Allah yang merupakan pejuang yang perkasa dan pahlawan perang yang mampu menyelamatkan Israel (bangsa atau kelompok tertentu) dalam suatu peperangan atau pergumulan yang sedang dihadapinya.

\section{Gideon dan Pergumulan "Kemelaratan"}

Bangsa Israel dalam zaman Gideon mengalami penindasan dari orang-orang Midian dan Amalek seperti terlihat dari catatan Kitab Hakim-Hakim 6: 1-6. Menurut Constable, sebenarnya

${ }^{30} \mathrm{G}$. Johanes Botterwech, Theological Dictionary Of The Old Testament, vol, I, 258-259.

${ }^{31}$ Dyrness, Tema-Tema Dalam Teologi Perjanjian Lama.

32 Holladay, Hebrew and Aramaic Lexicon of the Old Testament, 1381. Bible Works, V. 10.

${ }^{33}$ Kohler dan Baumgartner, Hebrew and Aramic Lexicon of the Old Testament. Bible Works, V. 10.

${ }^{34}$ Rabbi K.A. Schneider, a Jewish believer in Jesus and end-times messenger of the LORD, delivers the Word of the LORD with true passion of the Holy Spirit. https://www.amazon.com/Rabbi-K.A.-Schneider/e/B00992U4CE. Diakses pada tanggal 2 Oktober 2019 pukul 10.00 Wib. 
LOGIA : Jurnal Teologi Pentakosta

Vol. 1, No. 1 (Desember 2019)

ISSN : 2716-4322 (Cetak) 2716-2834 (Online)
Available Online at

http://sttberea.ac.id/e-journal/index.php/logia

DOI : $10.37731 / \log . v 1 i 1.23$

ada enam periode penindasan oleh musuh-musuh Israel selama 265 tahun yang dilaporkan oleh Kitab Hakim-Hakim. Periode pertama adalah 8 tahun penindasan oleh bangsa Mesopotomai yang akhirnya diakhiri oleh Otniel (Hak. 3: 7-11). Penindasan kedua datang dari bangsa Moab dan berlangsung 18 tahun. Ehud adalah hakim yang mengakhiri penindasan ini (3: 12-21). Ini diikuti dengan 20 tahun penindasan oleh bangsa Kanaan terutama yang dialami oleh Israel di utara (ps. 4-5). Barak dan Debora adalah pembebas yang diutus Allah dalam hal ini. Kemudian, datang penindasan oleh Midian selama 7 tahun, yang diakhiri oleh Gideon (6: 1-10;150). Penindasan kelima datang dari bangsa Amon di timur dan bangsa Filistin di barat (10;6-12:15). ${ }^{35}$

Bangsa Israel menderita selama penindasan 7 tahun oleh orang-orang Midian dan Amalek. Israel mengalami ketakutan terhadap orang-orang Midian sehingga membuat tempat-tempat perlindungan di pegunungan yaitu di gua-gua dan kubu-kubu. Dalam narasi pun diperlihatkan jelas oleh penulis bahwa Gideon sebagai bagian dari Isarel juga mengalami ketakutan. Dikisahkan bahwa Gideon mengirik gandum di tempat pengirikan anggur agar tersembunyi bagi orang-orang Midian. Selain itu, penindasan dari orang-orang Midian terhadap bangsa Isarel menjadikan mereka sangat melarat. Penulis memperlihatkan bahwa orang-orang Midian berkemah di daerah orang Israel, mereka memusnahkan hasil tanah tanpa meningggalkan bahan makanan apapun termasuk binatang ternak yaitu kambing, domba dan keledai.

Menurut Howard, dalam budaya orang-orang primitif masalah pangan menempati prioritas utama. Jadi alasan kesuburan tanah adalah yang terpenting dalam budaya seperti itu. ${ }^{36}$ Tanah yang subur mengahasilakan sumber makanan yang melimpah sehingga menjaga keberlangsungan suatu bangsa. Isarel pada waktu itu "menjadi sangat melarat" bukan karena mereka tidak bisa bercocok tanam, namun persoalnya orang Midian memusnahkan hasil hasil tanah mereka. Wright memahami situasi bangsa Isarel ini dari sudut pandang ekonomis. Menurutnya, Kitab Hakim-Hakim menunjukan penaklukan yang mula-mula ternyata belum sempurna. Tanah perjanjian masih menjadi tanah perjuangan: kekalahan yang panjang silih berganti dengan kemenangan yang diperoleh dengan susah payah dan hanya berusia pendek. Timbul kembali ketegangan didalam benak mereka, tidak lagi mengenai apakah Isarel akan masuk

\footnotetext{
${ }^{35}$ Roy B. Zuck, A Biblical Theology Of The Old Testament (Malang: Gandum Mas, 2005).175-176.

${ }^{36}$ David M. Howard Jr, Kitab-Kitab Sejarah Dalam Perjanjian Lama (Malang: Gandum Mas, 2002).130.
} 
LOGIA : Jurnal Teologi Pentakosta

Vol. 1, No. 1 (Desember 2019)

ISSN : 2716-4322 (Cetak) 2716-2834 (Online)
Available Online at

http://sttberea.ac.id/e-journal/index.php/logia

DOI : $10.37731 / \log . v 1 i 1.23$

ketanah perjanjian itu, tetapi apakah mereka dapat hidup didalamnya. ${ }^{37}$ Pergumulan tersebut membuat sangat merana apalagi dengan kemelaraatan yang sedang menimpa mereka.

\section{Ungkapan Sang Nabi}

Kemelaratan yang disebabkan oleh karena penindasan dari orang-orang Midian, membuat bangsa Israel berseru kepada Tuhan sehingga diutuslah seorang nabi sebagaimana terlihat dalam kisah Gideon khususnya dalam Hakim-hakim 6: 7-9. Dalam situasi kemelaratan bangsa Israel, ungkapan sang nabi mengingatkan tentang sejarah perbuatan Allah terhadap bangsa itu. Fakta historis mengesahkan bahwa Allah telah menuntun bangsa Isarel keluar dari penindasan bangsa Mesir, bahkan menurut Hinson peristiwa keluarnya bangsa Isarel dari Mesir adalah peristiwa inti dalam iman orang Yahudi. Orang Yahudi selalu mengingat masa ketika Allah bertindak membebaskan leluhur-leluhur mereka dari perbudakan di Mesir. ${ }^{38}$ Sepaham dengan Hinson, Davies seperti dikutip Barton mengatakan maksud keseluruhan memang untuk mengingat sejarah menurut pengertian para penyusunnya: guna mengenang perbuatanperbuatan besar Allah dalam sejarah bangsa tersebut, mengingat kembali masa perbudakan dan pembebasan, serta pemenuhan perjanjian Allah dengan umat Israel. ${ }^{39}$

Peristiwa Allah mengeluarkan bangsa Israel dari penindasan bangsa Mesir didahului dengan 10 tulah yang menunjukan keperkasaan Allah atas ciptaanNya. Lebih spesifik, menurut Schnittjer 10 tulah memperlihatkan keperkasaan Allah terhadap dewa-dewa Mesir. ${ }^{40}$

Tabel 1 Keperkasaan Allah Terhadap Dewa-dewa Mesir

\begin{tabular}{|l|l|}
\hline \multicolumn{1}{|c|}{ Bentuk Tulah } & \multicolumn{1}{c|}{ Dewa yang Ditaklukan } \\
\hline $\begin{array}{l}\text { Sungai Nil menjadi } \\
\text { darah }\end{array}$ & $\begin{array}{l}\text { Hapi (disebut juga Apis), dewa kerbau, dewa sungai Nil; Isis, dewi } \\
\text { Sungai Nil; Khnum, dewa kambing, penjaga Sungai Nil; dan lainya. }\end{array}$ \\
\hline
\end{tabular}

${ }^{37}$ Christopher Wright, Hidup Sebagai Umat Allah: Etika Perjanjian Lama (Jakarta: BPK Gunung Mulia, 2003).48.

${ }^{38}$ David F. Hinson, Sejarah Israel Pada Zaman Alkitab (Jakarta: BPK Gunung Mulia, 2004).66.

${ }^{39}$ Davies, Graham (2001). "Introduction to the Pentateuch". Dalam Barton, John. Oxford Bible Commentary. Oxford University Press. hlm. 37.

${ }^{40}$ Gary Edward Schnittjer, The Torah Story: An Apprenticeship On The Pentateuch (Malang: Gandum Mas, 2015).233. 


\begin{tabular}{|c|c|}
\hline Katak & Heqet, dewi kelahiran berkepala katak. \\
\hline Nyamuk & Set, dewa badai padang pasir. \\
\hline Lalat pikat & Re, dewa matahari; Uatchit, mungkin yang dilambangkan oleh lalat. \\
\hline $\begin{array}{l}\text { Kematian hewan- } \\
\text { hewan ternak }\end{array}$ & $\begin{array}{l}\text { Hathor, dewi berkepala sapi; Apis, dewa kerbau, lambang } \\
\text { kesuburan. }\end{array}$ \\
\hline Barah & $\begin{array}{l}\text { Sekhmet, dewi dengan kuasa atas penyakit; Sunu, dewa penyakit; } \\
\text { Isis, dewi penyembuh. }\end{array}$ \\
\hline Hujan es & $\begin{array}{l}\text { Nut, dewi langit; Osiris, dewa panen dan kesuburan; Set, dewa } \\
\text { padang pasir. }\end{array}$ \\
\hline Belalang & Nut, dewi langit; Osiris, dewa panen dan kesuburan. \\
\hline Kegelapan & $\begin{array}{l}\text { Re, dewa matahari; Horus, dewa matahari; Nut, dewi langit; Hathor, } \\
\text { dewi langit. }\end{array}$ \\
\hline Kematian anak sulung & $\begin{array}{l}\text { Min, dewa reproduksi; Heqet, dewi yang menyertai wanita selama } \\
\text { persalinan; Isis, dewi pe;indung anak-anak; putra sulung Firaun } \\
\text { dianggap dewa. }\end{array}$ \\
\hline
\end{tabular}

Peristiwa tersebut menunjukan bahwa keluarnya bangsa Israel dari perbudakan Mesir semata-mata karena perbuatan tangan Allah yang perkasa. Teologi kitab Hakim-Hakim menurut Howard mengutip dari Cundall mengatakan "Melalui pembacaan secara seksama kitab HakimHakim, orang tidak dapat melupakan kesan bahwa Allah muncul sebagai "pahlawan" dalam kitab ini, dan Dia bertindak bagi kebaikan Israel meskipun bangsa ini tidak setia." ${ }^{\prime 1}$ Telaah Cundall sangat tepat oleh karena pola pembebasan yang dikerjakan oleh Allah dalam peristiwa keluaran

\footnotetext{
${ }^{41} \mathrm{Jr}$, Kitab-Kitab Sejarah Dalam Perjanjian Lama.
} 
LOGIA : Jurnal Teologi Pentakosta

Vol. 1, No. 1 (Desember 2019)

ISSN : 2716-4322 (Cetak) 2716-2834 (Online)

juga terlihat dalam sepajang kisah Gideon.

dalam agama Kanaan seperti terlihat dalam tabel berikut ini: ${ }^{42}$

Tabel 2 Dewa-Dewi dalam Agama Kanaan

\begin{tabular}{|c|c|}
\hline Nama & Identifikasi \\
\hline $\mathrm{El}$ & $\begin{array}{l}\text { Kepala dari dewa-dewa Kanaan, bapk dari dewa-dewa dan orang } \\
\text { mati. Meskipun menjadi dewa kepala, ia relatif lemah dan tak } \\
\text { berdaya dibandingkan dewa Baal. }\end{array}$ \\
\hline Asyera & Dewa laut, istri dari dewa El, ibu dari semua dewa. \\
\hline Baal & $\begin{array}{l}\text { Dewa badai; akhirnya dia merupakan dewa paling hebat di antara } \\
\text { dewa-dewa lain karena berkaitan dengan kesuburan. }\end{array}$ \\
\hline Astarte & $\begin{array}{l}\text { Dewi kesuburan sekaligus dewi asmara dan peperangan, memiliki } \\
\text { kaitan erat dengan Baal. }\end{array}$ \\
\hline Anat & Dewi asmara dan peperangan, saudara sekaligus istri Baal. \\
\hline
\end{tabular}

Dalam kisah Gideon dewa yang ditaklukan oleh Allah adalah dewa Baal yaitu dewa badai yang merupakan dewa paling hebat dalam tradisi Kanaan (Hakim-Hakim 6: 25-40). Perlu digaris bawahi bahwa tindakan Allah untuk menaklukan dewa Baal khususnya dalam kisah Gideon tidak bisa dimaknai secara tunggal hanya menaklukan dewa Baal, namun tindakan tersebut juga harus dimaknai sebagai bagian integral dalam melepasakan Bangsa Israel dari kemelaratan oleh karena penindasan dari bangsa Midian. Hal ini berarti, penaklukan Baal oleh Allah Gideon sekaligus merupakan penaklukan terhadap Midian dan juga tindakan memerdekakan Banga Isarel dari kemelaratan.

\section{Gideon Sang Sopetim}

42 Ibid, 131-132.
Available Online at

DOI : $10.37731 / \log . v 1 i 1.23$ 
Hakim-hakim dalam bahasa Ibrani dikenal dengan nama Sopetim dan dalam bahasa Yunani Kritai. Di dalam bahasa Latin disebut Judicum. Istilah ini diberikan kepada pemimpin Israel selama periode sejak Yosua sampai ke Samuel. ${ }^{43}$ Hakim-hakim adalah seseorang yang dipanggil Allah sebagai para pemimpin untuk menegur bangsa Israel dari perbuatan-perbuatan dosa serta melepaskan mereka dari penindasan bangsa lain. Gideon adalah salah satu hakim yang hidup diantara Yosua dan Samuel yang bertindak mengadili umat Israel sekaligus memerdekakan mereka dari penindasan orang-orang Midian dan Amalek. Dalam Hakim-Hakim 6: 12 Malaikat Tuhan menampakan diri kepada Gideon dan menyebutnya sebagai "pahlawan yang gagah perkasa" yang dalam istilah Ibrani disebut dengan aִּּּ (gibbowr). Itulah sebabnya Kitab Hakimhakim 6-8 mengisahkan tentang kepahlawan dari Gideon sebagai seorang sopetim. Fakta demikian terlihat dalam pasal 6: 25-40 Gideon merobohkan mezbah Baal. Pasal 7: 1-25 Gideon memimpin pasukanya mengusir orang-orang Midian. Pasal 8: 4-21 Gideon mengalahkan orang Midian. Pasal 8: 22-28 Sesudah peristiwa penaklukan, Gideon diangkat menjadi pemimpin oleh rakyat Israel dan negeri itu aman selama 40 tahun pada masanya.

Meskipun demikian keadaanya, namun dalam pasal 6: 12-15 dikisahkan oleh penulis bahwa Gideon adalah seorang penakut dan tidak percaya diri. Hal itu terihat dari fakta bahwa dia bersembunyi dari orang Midian ketika mengirik gandum dan mengatakan berasal dari suku manasye - suku terkecil dalam Israel ketika Tuhan memanggilnya menjadi sopetim. Bahkan ketika Allah berujar akan menyertainya dia meminta tanda dari bukti Penyertaan-Nya (6: 17-22; 36-40). Hill dan Walton memberikan Analisa yang tajam berkaitan dengan keberadaan para hakim-hakim Israel termasuk juga Gideon dalam kiprahnya yang menakjubkan;

Memang para hakim bertindak sebagai wakil Allah membebaskan bangsa dari penindasan asing, namun sebagian besar dari mereka menunjukan perilaku serta sifat-sifat pribadi agak kasar dan bahkan penuh dosa. Perhatikan misalnya, betapa ngerinya kisah rinci bagaimana Ehud membunuh Eglon (3: 21-22, 24), Gideon membawa Isarel pada kemurtadan bangsanya (8: 24-27), kekejaman Abimelekh membakar musuhnya (pasal 9),

\footnotetext{
43 Ibid, 122.
} 
nazar Yefta yang begitu gegabah (11: 30-31, 34-40), dan tingkah laku Simson yang aneh (pasal 13-16). ${ }^{44}$

Analisa dari Hill dan Walton sesuai dengan pandangan Fee dan Stuart bahwa dalam hikayat Alkitab, Allah merupakan pahlawan dalam cerita itu. Tokoh cerita, peristiwa, perkembangan jalan cerita, dan klimaksnya, semuanya terjadi, tetapi di balik hal-hal, maka Allah yang menjadi pelaku utama atau tokoh utama yang menentukan dalam semua hikayat itu. ${ }^{45}$ Pratt memiliki sudut pandang yang senada dengan Fee dan Stuart tentang hikayat bahwa Allah memainkan peran sentral dalam banyak teks, berinteraksi secara ekstensif dengan mahluk ciptaan-Nya dan mengatur segala peristiwa. ${ }^{46}$ Jadi dapat dikatakan bahwa Gideon adalah seorang pahlawan yang gagah perkasa namun pahlawan perang yang sesungguhnya adalah Allah sendiri yang menaklukan Baal, orang-orang Midian dan membebaskan Isarel dari kemelaratan. Tokoh utama di balik kisah Gideon adalah Allah.

\section{Konstruksi Teologi Kontekstual Asia Berdasarkan Fakta El Gibor Dalam Kisah Gideon Dan Pergumulan Kaum Miskin Asia}

Kontruksi merupakan suatu kegiatan membangun sarana maupun prasarana. Kontruksi Teologi kontekstual Asia berdasrkan fakta El Gibore dalam kisah Gideon merupakan usaha membangun sarana dan prasarana bukan dalam arti fisik melainkan sarana prasarana dalam sudut pandang teologis yang mencakup dimensi kemiskinan dari kedua konteks, hakekat kelompok manusia dalam realitas kemiskinan dan teisme kontekstual bagi pergumulan kaum miskin Asia.

\section{Perjumpaan Kemiskinan Asia dan Israel Zaman Gideon}

Asia dan Israel zaman Gideon sama-sama mengalami pergumulan kemiskinan yang mencakup dimensi ekonomis, sosiologis, psikologis dan mesianis. Dalam dimensi ekonomis terlihat bahwa masalah kemiskinan menyebabkan mereka hidup dalam lingkaran

${ }^{44} \mathrm{Jr}$, Kitab-Kitab Sejarah Dalam Perjanjian Lama.

${ }^{45}$ Gordon D. Fee and Douglas Stuart, Hermeneutik: Bagaimana Menafsirkan Firman Tuhan Dengan Tepat (Malang: Gandum Mas, 2003).77.

${ }^{46}$ Richard L. Pratt, He Gave Us Stories: The Bible Student's Guide To Interpreting Old Testament Narratives (Surabaya: Momentum, 2005).149. 
LOGIA : Jurnal Teologi Pentakosta

Vol. 1, No. 1 (Desember 2019)

ISSN : 2716-4322 (Cetak) 2716-2834 (Online)

ketidakberdayaan. Dalam konteks Asia karena ketidakberdayaan itu, mereka mengalami rendahnya tingkat pendidikan, produktivitas kerja, kesehatan dan gizi. Sedangkan dalam konteks Israel zaman Gideon, karena ketidakberdayaan itu mereka mengalami pergumulan untuk bertahan hidup. Itulah sebabnya demi untuk memiliki gandum sebagai sumber makanan utama Gideon bersembunyi di tempat pemerasan anggur untuk mengirik gandum. Apa yang dilakukan oleh Gideon kemungkinan merepresentasikan usaha rakyat Israel pada waktu itu untuk bertahan hidup. Dalam budaya masyarakat Israel pada waktu itu, masalah pangan merupakan prioritas utama karena menentukan keberlangsungan bangsa itu sebagai umat pilihan Allah.

Dalam dimensi sosiologis terlihat bahwa masalah kemiskinan Asia menyebabkan terjadinya kelas sosial dimana kaum kaya memperbudak kaum miskin demi semakin bertambah kaya. Namun disisi lain, kemiskinan melahirkan solidaritas yang menjadikan mereka sanggup bertahan hidup. Penindasan dari kelas sosial yang lebih tinggi terhadap kelas yang lebih rendah juga dialami oleh Israel pada zaman Gideon yang mengalami kemelaratan oleh karena penindasan dari orang-orang Midian dan Amalek. Israel pada zaman Gideon menjadi suatu bangsa yang tertindas dan tidak hidup dalam kemerdekaan karena dikuasai oleh para penindas. Penindasan itu menyebabkan ketakutan sehingga membuat mereka bersembunyi dipegunungan dan di guagua untuk bertahan hidup.

Dalam dimensi psikologis terlihat bahwa masalah kemiskinan Asia menyebabkan kaum miskin merasa terasing, menderita dan merana bahkan merasa tidak memiliki martabat. Keinginan untuk lepas dari situasi ini kemudian menyebabkan kaum miskin Asia hidup dalam harapan mesianis sebagai salah satu alternatif pembebasan mereka dari kemiskinan. Dalam situasi Israel pada zaman Gideon, harapan untuk terlepas dari penindasan orang-orang Midian yang menyebabkan kemelaratan maka orang-orang Israel berseru kepada Tuhan. Tuhan mendengar seruan orang-orang Isarel sehingga mengutus Malaikat dan memanggil Gideon sebagai seorang sopetim bagi mereka. Asia dalam konteks kemiskinan membutuhkan Gideon sebagai model manusia yang membebaskan seperti halnya yang sudah dikerjakan oleh Toyohiko 
Kagawa yang melayani sebagai sosialis Kristen dengan memanusiakan manusia masyarakat miskin. Apa yang dikerjakan Kagawa juga menjadi tugas setiap orang Kristen. ${ }^{47}$

\section{Kaum Tertindas dan Penindas: Perlu Kasih Allah}

Manusia dalam konteks pergumulan kaum miskin Asia dan kemelaratan Israel zaman Gideon terbagi menjadi 2 kelompok yaitu kaum tertindas dan kaum penindas. Dalam konteks kisah Gideon para penindas adalah orang-orang Midian dan Amalek sedangkan yang tertindas adalah orang Israel. Penganiayaan yang menyebabkan Isarel melarat didasarkan pada kenyataan bahwa mereka telah berbuat dosa, dan meninggalkan kasih Allah. Dalam konteks Asia kaum tertindas adalah kaum miskin Asia yaitu mereka yang sakit, terlantar, kelaparan, kaum buruh, para pekerja seksual, masyarakat kumuh, anak-anak jalanan dll. Kaum penindas dalam konteks Asia adalah kaum elit atau kaya yang demi mencapai kepentingan-kepentinganya rela memperdaya atau menindas kaum miskin. Kaum tertindas dan penindas merupakan bagian dari manusia yang memerlukan Kasih Allah. Dengan kasih Allah yang bekerja dalam kehidupan mereka, maka prinsip keadilan ekonomi dapat terbangun sehingga masalah kemiskinan Asia dapat diurai. Para penindas yang mengalami kasih Allah akan memandang sesama yang miskin sebagai bagian dari kehidupan mereka yang memerlukan pertolongan dan kemerdekaan. Jika mereka adalah kaum buruh maka sudah sewajarnya mendapat upah yang sesuai dengan waktu bekerja. Para tertindas akan merasakan kasih Allah melalui perbuatan kasih dari para penindas yang telah mengalami kasih Allah. Disinilah berita tentang kasih Allah perlu didengungkan oleh orang-orang Kristen dalam realitas Asia yang miskin.

\section{Teisme Dalam Pergumulan Kaum Miskin Asia}

Allah adalah Allah yang memperjuangkan nasib kaum miskin Asia. Sebagaimana El Gibore dalam kisah Gideon tampil sebagai Allah yang melepaskan bangsa Israel dari kemelaratan karena penindasan orang-orang Midian, maka tema tentang Allah sebagai pejuang kemiskinan menjadi sangat kontekstual dalam realitas Asia. Realitas demikian menjadikan masyarakat miskin Asia memiliki harapan untuk terlepas dari penderitan yang menimpanya. Bahkan Allah sang pejuang bagi nasib kaum miskin hadir dalam setiap pergumulan dan penderitaan yang mereka alami

\footnotetext{
${ }^{47}$ Yung, "Mangga Atau Pisang? Sebuah Upaya Pencarian Teologi Kristen Asia Yang Autentik."199
} 
LOGIA : Jurnal Teologi Pentakosta

Vol. 1, No. 1 (Desember 2019)

ISSN : 2716-4322 (Cetak) 2716-2834 (Online)
Available Online at

http://sttberea.ac.id/e-journal/index.php/logia

DOI : $10.37731 / \log . v 1 i 1.23$

sebagaimana Dia menyertai Gideoan dan Israel. Kehadiran dan penyertaan-Nya menjadi real ketika kaum miskin Asia berseru-seru kepadaNya karena selain Allah hadir dalam penderitaan kaum msikin Asia, Dia juga merupakan Allah yang berdaulat dalam sejarah umat manusia. Menurut Song, Yesus yang 'berwajah' Asia merupakan Allah yang mencoba hadir dalam duka dari orang-orang Asia yang tertindas. ${ }^{48}$

Persoalanya, bagaimana menghadirkan Allah yang memperjuangkan nasib orang miskin Asia? menghadirkan Allah yang demikian menjadi tugas dari setiap manusia yang sudah mendapatkan anugerah pengampunan dari Allah. Jika muara dari kemerdekaan kemiskinan adalah pengharapan mesianis, maka tugas manusia yang sudah mendapatkan anugerah pengampunan dari Allah adalah bekerja dan melayani dalam usaha-usaha berdimensi ekonomis, sosiologis dan psikologis. Dengan kata lain, kehadiran Allah terlihat dalam dimensi-dimensi tersebut. Allah yang memperjuangkan nasib orang miskin harus diterjemahkan dalam programprogram kekristenan. Dimensi ekonomis, sosiologis dan psikologis harus dimanifestasikan dalam kehidupan real. Program-program misi dan pelayanan gereja harus bersifat holistik yang menyentuh kaum miskin Asia. Misalnya: pelatihan ekonomi kreatif, program bimbingan belajar, pembukaan sekolah bagi kaum miskin, pelayanan kesehatan bagi kaum miskin, bimbingan konseling diluar gereja, dll.

\section{KESIMPULAN}

Allah yang memperjuangkan nasib orang miskin harus dihadirkan dalam realitas Asia yang miskin dengan program-program misi dan pelayanan Gereja yang bersifat holistik. Tindakan yang demikian sekaligus memanifestasikan kasih Allah bagi dua kelompok manusia, baik yang miskin maupun yang kaya.

48 Joachim, Huang. "Tinjauan Buku Sebutkanlah Nama-Nama Kami: Teologi Cerita Dari Perspektif Asia" Jurnal Pelita Zaman Vol. 5 No. 1 (Tahun 1990): diakses 21 November 2019, http://alkitab.sabda.org/resource.php? topic $=236 \&$ res $=$ jpz 


\section{DAFTAR PUSTAKA}

A.A Yewangoe. Theologia Crucis Di Asia: Pandangan-Pandangan Orang Kristen Asia Mengenai Penderitaan Dalam Kemiskinan Dan Keberagaman Di Asia. Jakarta: BPK Gunung Mulia, 2004.

Andreas B. Subagyo. Pengantar Riset Kuantitatif Dan Kualitatif. Bandung: Kalam Hidup, 2004.

Berkhof, Louis. Teologi Sistematika: Doktrin Allah. Lembaga Reformed Injili Indonesia, 1997.

Bevans, Stephen Bennet. Model-Model Teologi Kontekstual. Flores: Penerbit Ledalero, 2002.

Daniel K. Listijabudi. Bergulat Di Tepian: Pembacaan Lintas Tekstual Dua Kisah Mistik (Dewa Ruci Dan Yakub Di Yabok Untuk Membangun Perdamaian. Jakarta: BPK Gunung Mulia, 2019.

Drewes, B.F., and Julianus Mojau. Apa Itu Teologi? Pengatar Ke Dalam Ilmu Teologi. Jakarta: BPK Gunung Mulia, 2003.

Dyrness, William. Tema-Tema Dalam Teologi Perjanjian Lama. Malang: Gandum Mas, 2004.

Emanuel Gerrit Singgih. Iman Dan Politik Dalam Era Reformasi Di Indonesia. Jakarta: BPK Gunung Mulia, 2002.

Erwan Agus Purwanto. “Mengkaji Potensi Usaha Kecil Dan Menengah (UKM) Untuk Pembuatan Kebiiakan Anti Kemiskinan Di Indonesia." Jurnal IImu Sosial dan IImu Politik 10, no. 3 (2019): 295-296.

Fee, Gordon D., and Douglas Stuart. Hermeneutik: Bagaimana Menafsirkan Firman Tuhan Dengan Tepat. Malang: Gandum Mas, 2003.

Herlianto. Siapakah Yang Bernama Allah Itu? Jakarta: BPK Gunung Mulia, n.d.

Hinson, David F. Sejarah Israel Pada Zaman Alkitab. Jakarta: BPK Gunung Mulia, 2004.

Jr, David M. Howard. Kitab-Kitab Sejarah Dalam Perjanjian Lama. Malang: Gandum Mas, 2002.

Kalis Stevanus. “Mengimplementasikan Pelayanan Yesus Dalam Konteks Misi Masa Kini Menurut Injil Sinoptik." Jurnal Fidei 1, no. 2 (2018): 287. 
Laksmi. "Kemiskinan Informasi Pada Masyarakat Marjinan Di Indonesia." Jurnal Al-Maktabah 4, no. 2 (2004): 93-94.

Miles, M. B., and A. M. Huberman. Qualitative Data Analysis: A Sourcebook of New Methods; Qualitative Data Analysis: A Sourcebook of New Methods. California: Sage Publication Inc, 1994.

Mulyono, Sungkowo Edy. “Model Pemberdayaan Masyarakat Miskin Melalui Jalur Pendisikan Formal Di Kecamatan Gajah Mungkur Kota Semarang." Jurnal Edukasi 2, no. 1 (2017): 1.

Nano Prawoto. “Memahami Kemiskinan Dan Strategi Penanggulangannya." Jurnal Ekonomi dan Studi Pembangunan 9, no. 1 (2009): 56-68.

Pieris. "The Dinamic of the Act, a Reply to the Editor of Satyodaya." Bulletin Of Satyodaya Centre for Social Research and Encounter 7, no. 3 (1979): 23-28.

Pratt, Richard L. He Gave Us Stories: The Bible Student's Guide To Interpreting Old Testament Narratives. Surabaya: Momentum, 2005.

Rini, Ayu Setyo, and Lilik Sugiharti. “Faktor-Faktor Penentu Kemiskinan Di Indonesia: Analisis Rumah Tangga." Jurnal Ilmu Ekonomi Terapan 1, no. 2 (2016).

Sairin, Weinata. Iman Kristen Dan Pergumulan Kekinian. Bandung: Bina Media Informasi, 2012. Schnittjer, Gary Edward. The Torah Story: An Apprenticeship On The Pentateuch. Malang: Gandum Mas, 2015.

Sugirtharajah, R.S. Wajah Yesus Di Asia. Jakarta: BPK Gunung Mulia, 1996.

Tissa Balasuriya. Teologi Siarah. Jakarta: BPK Gunung Mulia, 2004.

Widyamadja, Josef P. Yesus Dan Wong Cilik: Praksis Diakonia Transformatif Dan Teologi Rakyat Di Indonesia. Jakarta: BPK Gunung Mulia, 2017.

Wright, Christopher. Hidup Sebagai Umat Allah: Etika Perjanjian Lama. Jakarta: BPK Gunung Mulia, 2003.

Yung, Hwa. “Mangga Atau Pisang? Sebuah Upaya Pencarian Teologi Kristen Asia Yang Autentik." Literatur Perkantas (2017): 199. 
LOGIA : Jurnal Teologi Pentakosta

Vol. 1, No. 1 (Desember 2019)

ISSN : 2716-4322 (Cetak) 2716-2834 (Online)

Zuck, Roy B. A Biblical Theology Of The Old Testament. Malang: Gandum Mas, 2005.
Available Online at http://sttberea.ac.id/e-journal/index.php/logia DOI : $10.37731 / \log . v 1$ il.23 